\title{
Effects of Temperature and Moisture on Phenology and Productivity of Indian
} Ricegrass

\author{
L.C. PEARSON
}

\section{Abstract}

Growth in Indian ricegrass commenced in the spring when soil temperatures stayed at $4^{\circ} \mathrm{C}$ for at least 3 or 4 days. Maximum plant size was attained when (1) soils warmed up early in the spring, (2) soil temperatures were relatively low later in the spring, and (3) additional water was supplied during the spring growth period. Higher soil temperature late in the vegetative phase of growth delayed anthesis approximately 3 days for each degree Celsius above $10^{\circ} \mathrm{C}$. Additional moisture early in the season also delayed anthesis. Relatively reliable estimates of foliage biomass and seed biomass were made from measurements of average and/or maximum plant height, average length of longest leaf on each culm, maximum seed stalk height, clump diameter, and number of culms per plant. Measurements of biomass of needleandthread grass indicate that the generalized formulas presented here should be applicable to other cool-season bunchgrasses.

Although slight differences in temperature and moisture conditions from year to year affect rangeland productivity, the degree of the effect and the way in which these differences affect individual species have been little studied. Blaisdell (1958) observed that growth and development in grasses during the early part of the growing season are closely correlated with soil temperature, while development during the latter part of the growing season is more closely associated with precipitation. Additional observations indicate that shrubs are generally most productive during late winter and early spring, forbs later in the spring, and grasses in the late spring and early summer (Blaisdell 1958; Pearson 1965). In the northern half of the intermountain area, cool-season bunchgrasses are the most important range plants from the point of view of total productivity as well as of topgrowth production utilized by range livestock and wild game.

Indian ricegrass (Oryzopsis hymenoides [Roem. and Shult.] Ricker), is a relatively abundant species of greatest significance in the middle stages of ecological succession on sandy soils (Chadwick and Dalke 1965). It is frequently associated with needleandthread grass (Stipa comata Trin. and Rupr.), but is usually less abundant. It is highly palatable to livestock and wild game and is of anthropological interest because it was important

\footnotetext{
The author is professor of biology at Ricks College, Rexburg, Idaho.

This study was supported by funds from the Desert Biome Project, US/IBP. Neal Hayes and David Merkley, Ricks College students, gathered much of the data; several other Ricks students also worked on the project. Gordon Hoagland, Mathematics Department, wrote the FORTRAN program for the analysis of the 1972 data and reviewed some of the other computer programs: Sam Brewster, Jr., Biology Department, offered helpful criticisms and suggestions. Fred Wagner, of Utah State University and associate director of the Desert Biome, and the personnel at the Ecology Center, Utah State Univ., were always very helpful as well as patient during the course of the study, and their assistance is gratefully acknowledged.

Manuscript received March 10, 1978
}

to Indians as a food supply. It is a long-lived grass forming large clumps which eventually become "doughnut-shaped" as a result of the oldest culms dying. Large, open seedheads provide positive identification of Indian ricegrass, even at a distance (Robcrtson 1977a, b). Because it is an important species in Curlew Valley on the Utah-Idaho border, it was chosen for a model of the cool-season bunchgrasses at the Desert Biome sites, U.S. International Biological Program (IBP) there.

The main objective of this study was to ascertain the general configuration of the growth curve of Indian ricegrass and how it is affected by small changes in temperature and moisture: predictions of this species' contribution to the total energy budget under varying climatic conditions can then be madc. To reach this objective, measurements were made of soil temperature and moisture and plants were irrigated in late May and late June of 1971. Secondary objectives included (1) estimating dry weight from linear measurements so that productivity can be studied without destructive sampling, and (2) investigating the reliability of Indian ricegrass as a model for productivity of other cool-season grasses such as needleandthread grass.

The study was conducted at four sites in the vicinity of Rexburg, Idaho, and two sites in Curlew Valley (Fig. 1). Five of the six sites were moderately-to-heavily grazed by cattle and/or sheep; one, the Ricks College site, was not grazed. Data were analyzed with the aid of the Ricks College Computer Center and the Ecology Center at Utah State University: data are stored under the following DSCODES at Utah State University: A3UPC01, 02, 03, 04, and 05.

\section{Methods}

To analyze the pattern of growth and development, two kinds of data were utilized. (1) Every 15 to 20 days from May 20 to August 4, 1971,35 plants were excavated, brought into the laboratory, carefully cleaned of soil, and separated into root, crown, foliage, and fruit-seed portions, which were then oven dried at $65^{\circ} \mathrm{C}$ and weighed. Dry weight was plotted against time, and separate free hand curves were drawn on clear sheets of plastic for foliage, roots, crowns, and fruits (Fig. 2). Methods outlined by Ezekiel (1941) for curvilinear relationships between two variables were followed. The curves were made as simple and smooth as possible to represent our best least-square estimate of biomass change with time consistent with our present knowledge of photosynthesis, food storage, and translocation in plants. Generalized formulas for several geometric figures were compared with these curves. Coefficients for the formulas were read into the computer and then automatically and systematically varied: the resulting computer-generated curves were covered with the plastic sheets on which the curves from the data had been produced and when an essentially perfect fit for any major section of the curve was found, 


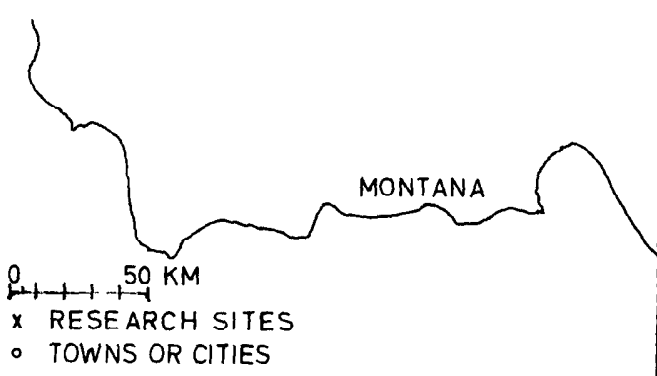

SANJ DUNES $x$

PLANO $x$ OST. ANTHONY

MENAN BUTTES $x q^{\text {REXBURG }}$

RICKS COLLEGE

IDAHO FALLS

- POCATELLO

$x$ CURLEW NORTH

'HOLBROOK

'SNOWVILLE

UTAH

${ }^{x}$ CURLEW SOUTH

- LOGAN

Fig. 1. Map of eastern Idaho and northern Utah showing the location of the six study sites.

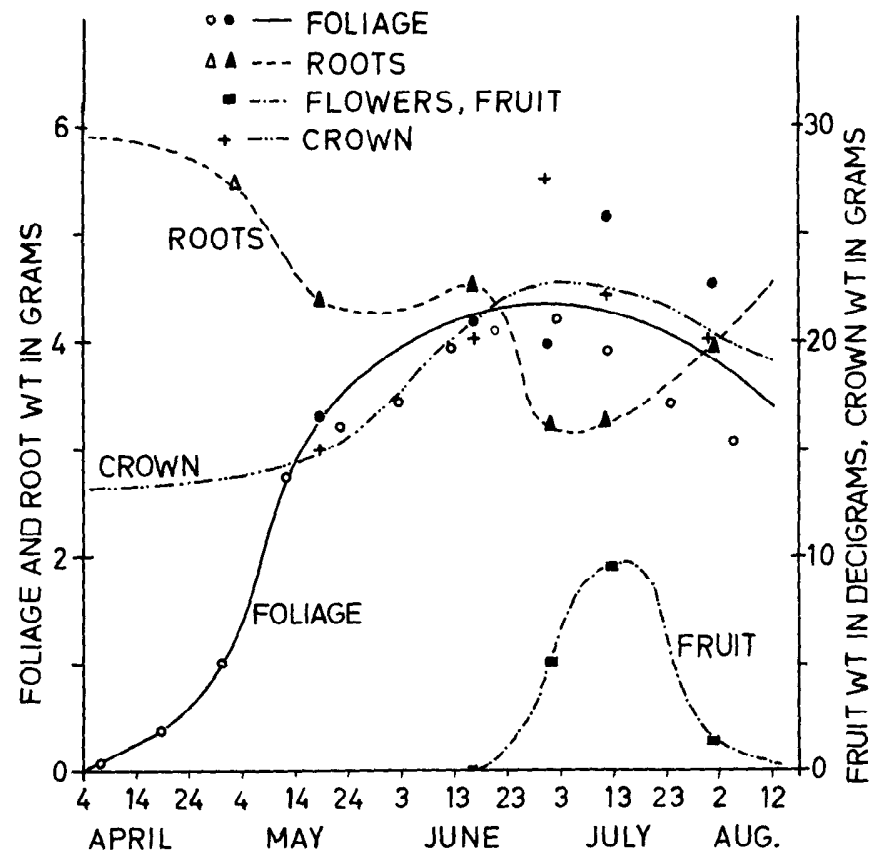

Fig. 2. Pattern of growth in Indian ricegrass at the four Rexburg sites in eastern Idaho in 1971. Each open circle or triangle is the average estimated weight of 281 plants: each of the closed symbols and crosses is the average harvested weight of 35 plants (or of 20 plants prior to June 18). the coefficients were recorded and kept. (2) Every 10 days from May 15 until August 5, 1971, each plant was examined and the number of culms per plant, maximum leaf length, length of each leaf on each of five randomly chosen culms, average number of leaves per culm, crown diameter (at 0, 120, 240 degrees from north-south), maximum height of the seed heads, number of seed heads per plant and average number of seeds per head were carefully measured. From these measurements, dry weights of the 281 living plants were estimated and these estimated weights were also plotted against time on the plastic sheets. Soil temperature was measured at $20-\mathrm{cm}$ depth on the north side of and adjacent to each plant, precipitation for the week was recorded, and subjective evaluations were made of the amount of grazing on each plant and of the percent weed cover adjacent to each plant. Additional measurements were made of many of the plants in the spring of 1972,1973 , and 1975 .

These data were obtained from 281 Indian ricegrass plants and 49 needleandthread grass plants selected on the basis of uniformity and proximity to each other at the four Rexburg sites, plus 51 Indian ricegrass plants in Curlew Valley. The experimental design for the main study at Rexburg was a modified $7 \times 8$ factorial with five replications of 50 plants each; the additional 31 plants, 6 or 7 in each replication, provided a "reserve"' in case of gopher or other damage. At the time of selection, plants as nearly alike as possible on the basis of number of culms, crown diameter, and height were placed in blocks of seven. Eight such blocks of seven were grouped together to make up each of the five replications. The seven plants in each block were harvested the same day, one block from each replication on each harvest date. This design was used in order to obtain more meaningful comparisons (lower standard errors) among the different irrigation treatments, but it was at the expense of a higher standard error for harvest date differences and probably accounts for some of the discrepancy in Figure 2 between harvest dry weight and estimated dry weight, especially on the July 10 and August 1 harvests. Harvesting was by shovel, care being taken to obtain all of the roots. Careful screening of the soil around some of the plants after excavation indicated that loss of roots never exceeded 1 or $2 \%$ of the total root dry weight in this study.

Numbered stakes exactly 1 meter north of each plant identified the individual plants; the distance and direction from one stake to the next in sequence was recorded in the field book. Adjacent to each stake, a partially buried metal can served as a rain gauge. A film of oil in the the can reduced evaporation between measurements. All 330 plants in the Rexburg area were measured on the same day (if possible-or on consecutive days) at 10-day intervals; the Curlew Valley plants were measured less often.

The seven irrigation treatments included every possible combination of 0,4 , and $8 \mathrm{~cm}$ of water and early (May) and late (June) application, viz., 0-0, 4-0, 8-0, 0-4, 0-8, 2-2, and 4-4 cm. For the first two harvest dates, only one irrigation treatment could precede harvesting and hence the total of 50 instead of 56 plants in each replication.

Within each block of seven plants, assignment to irrigation treatment was random. Plants were irrigated by hand using buckets and an irrigation frame made of metal, $60 \mathrm{~cm}$ square and about $15 \mathrm{~cm}$ high. The frame was so placed that the plant was in the middle of the framed area and it was then driven into the soil just deep enough to form a dam. When 14.4 liters of water were poured into the frame, the equivalent of $4 \mathrm{~cm}$ precipitation had been applied to that area.

The dry weights of 142 harvested plants were compared with number of culms, plant height, and other linear measurements taken on these same plants just prior to harvesting. With help of the computer, formulas for estimating dry weight from these parameters were derived. To aid in this, some of the plants harvested in 1972 were divided into individual culms and individual roots prior to weighing and further measurements made of culm diameter, leaf width, leaf length, root diameter, number of branch rootlets per root, and root length. 


\section{Results}

Every 2 to 3 weeks, beginning May 20, 35 plants were harvested, dried, and weighed; the average dry weights are shown in Figure 2 (closed symbols and crosses). Approximately every 10 days, beginning April 7, the dry weight of each of 281 plants was estimated from the number of culms, maximum leaf length, average leaf length, crown diameter, and number of seeds. Averages of these estimated weights are shown in Figure 2 as open circles or triangles. On the last two harvest dates, foliage harvest weight was considerably greater than the estimated weight probably because the plants in the blocks harvested on those dates happened to be larger initially.

The dry weight of the foliage, indicated in Figure 2 by the solid line, increased very slowly at first, increased at an accelerating rate until shortly before anthesis, increased more slowly until maturity, and finally decreased. Fruit weight (solid rectangles) increased very rapidly following the onset of anthesis and decreased almost as rapidly as the seeds matured and were either consumed by insects or other animals or disseminated by wind or animals. The dry weight of the crowns-the woody, perennial portion of the plants at or just below ground level from which both the green shoots and roots originate--also gradually increased until the peak of anthesis and then decreased. Thus, simple, smooth curves could be drawn when 1971 dry weights were plotted against time for these plant parts. Root dry weights, on the other hand, changed more erratically (Fig. 2 dashed line).

Rates of growth were different at the different sites, being most rapid at the Curlew Valley south site and slowest at Plano. These differences were probably due to both environmental and genetic factors (McMillan 1959, 1961). Of the four Rexburg sites, growth began earliest and was most rapid at the southfacing Menan Butte site, where it commenced in late March in 1971 and the first of April in 1973; growth was almost as rapid at the Sand Dunes site (note the high values for coefficients B anc $C$ in Table 1), where it began the latest but where the soil warmed up quickly.

Examination of Figure 2 suggests that Indian ricegrass goes through four distinct phenological stages. Our observations of other cool-season bunchgrasses indicate that they go through the same stages. These, together with substages, are indicated in the following outline:

1. Sprouting stage in spring as dormancy is broken

2. Vegetative growth stage

a. Logarithmic phase

b. Decelerating phase

3. Anthesis and maturation stage

a. Weight increase phase

b. Weight decrease phase

4. Dormancy stage
a. Summer-fall phase
b. Winter phase

During the sprouting stage, foliage weight increases but total plant weight decreases as food reserves in the roots are heavily drawn upon. Observations made in 1971, 1973, and 1975 indicate that growth in the spring begins when soil temperatures at the $15-\mathrm{cm}$ depth have warmed up to about $4^{\circ} \mathrm{C}$ and remain there for at least 3 or 4 days. Experiments conducted in the spring of 1977 by Ricks College students with crested wheatgrass (Agropyron desertorum (Fisch.) Schult.) indicate that it takes about a week at the "critical" temperature or lowest temperature at which sprouting will occur but is somewhat

Table 1. Comparison of environmental conditions at the six sites, 1971 beginning dates of the phenological stages of Indian ricegrass, and 1971 growth rate coefficients for use in Formulas (1) to (5).

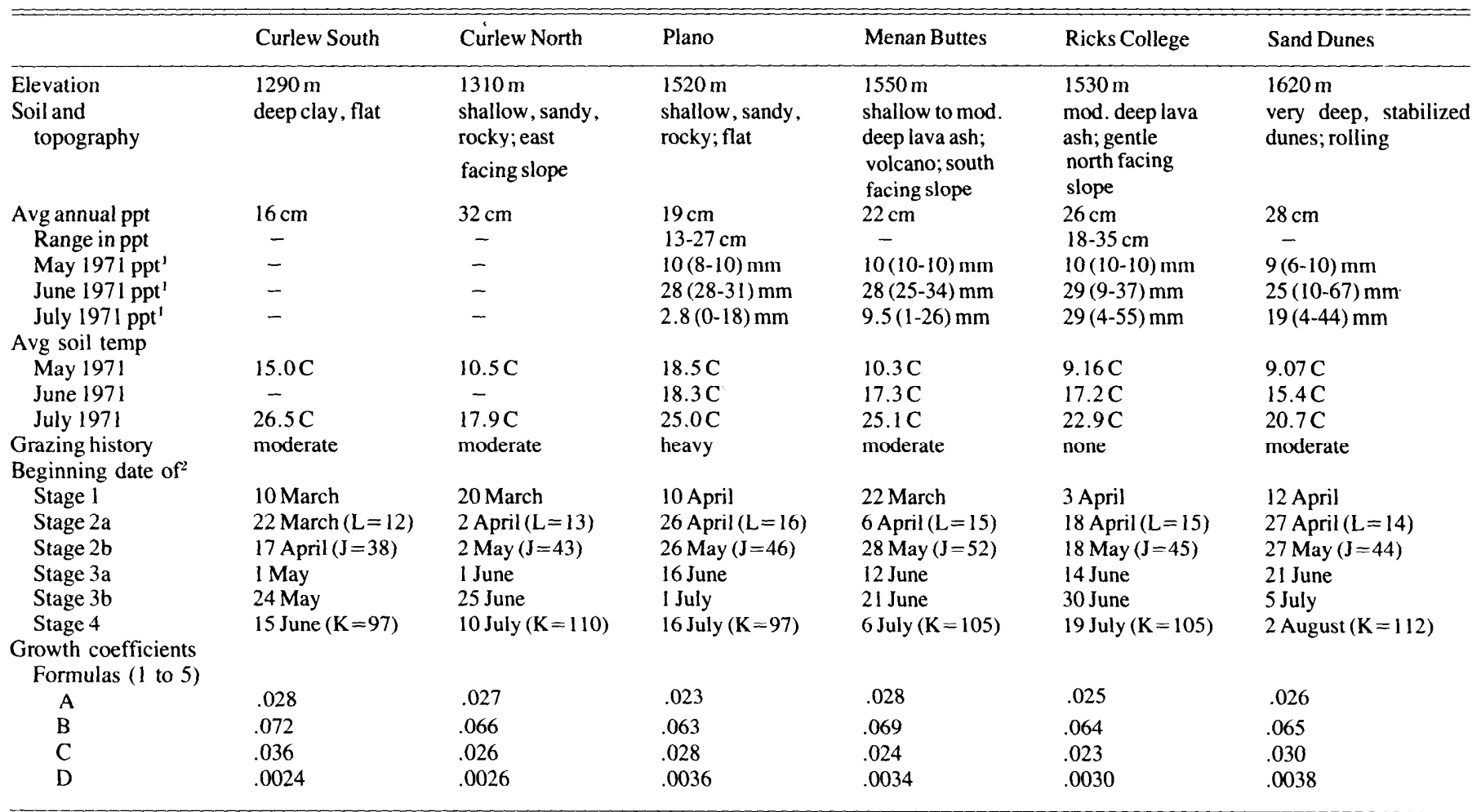

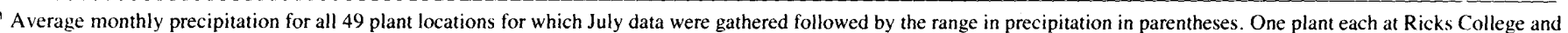
Menan Buttes received 0 precipitation in July according to the record; these were ignored in showing the range and in calculating the average.

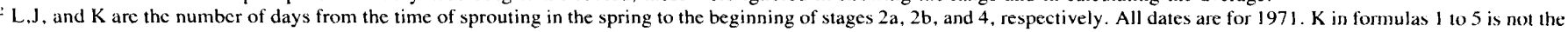
same as $\mathrm{K}_{\mathrm{i}}$ in formulas 6 to 8 . 
faster at slightly higher temperatures. During the sprouting stage, foliage production appears to be essentially linear; in 1971 it lasted about 15 days (Table 1, Fig. 2).

The vegetative growth stage begins when the compensation point is reached-i.e. when daily photosynthesis equals daily respiration-and continues until the beginning of anthesis. As foliage weight increases, the amount of chlorophyll and hence the rate of photosynthesis also increase during the first part of this stage (2a); during the second part of the stage (2b) foliage dry weight increases less rapidly. We would expect root weight to continue to decrease during the first part of this stage as stored food is used in sending out new shoots and to increase in the second part as photosynthate from the foliage is translocated to the roots. Our 1971 data appear to confirm this (Fig. 2).

The anthesis and maturation stage begins when the first florets emerge from the boot and continues until the seeds mature and the plants become dry. Foliage dry weight increased during the first part of this stage (3a) in 1971 at the same rate as in the late vegetative stage ( $2 \mathrm{~b}$ ). Just before the seeds matured, however, foliage dry weight began to decrease (Stage 3b). Flowers, fruits, and seeds increased in weight until just before maturation and then decreased. Root weight decreased as flowers and fruit formed and then increased as the tops approached maturity (Fig. 2).

The dormancy period can arbitrarily be divided into two phases: the summer-fall phase (4a), characterized by little litter accumulation, which lasted until about December 15 in 1971, and a winter phase (4b), characterized by the tops and leaves being battered down by wind and snow so that a relatively small percentage of the old seed stalks were still standing by April 1972. During the first part of the stage, there appeared to be considerable translocation of food substances into the roots (Fig. 2).

When the foliage curve in Figure 2 was compared with 120 computer-generated growth curves, the following formulas were obtained:

$$
\begin{aligned}
& \text { Stage } 1-F_{i+1}=F_{i}+A \\
& \text { Stage } 2 a-F_{i+1}=F_{i}+B F_{i} \\
& \text { Stages } 2 b, 3-F_{i+1}=F_{i}+C F_{i}-D F_{i}^{t} \\
& \text { Stage 4-F } F_{i+1}=F_{i}-\frac{1}{365-K} F_{k}
\end{aligned}
$$

Where $F_{i}$ is the foliage weight of a plant on the $i$ th day after sprouting begins in the spring, $F_{i+1}$ is the foliage weight on the day after the $i$ th day and $F_{k}$ is the foliage weight on the day when $\mathrm{I}=\mathrm{K}$. Values for A,B,C,D, and $\mathrm{K}$ are given in Table 1 . The $t$ factor in formula (3) is an exponent consisting of two parts: a time factor and a vigor factor. As the computer automatically "experimented" with different exponents to produce a curve that would exactly match this portion of Figure 2, it came up with a formula which can be expressed this way:

$$
t=\frac{I+L}{2(J-L)}+\frac{4}{F_{i}}
$$

The values for $\mathrm{J}$ and $\mathrm{L}$ are found in Table 1 for 1971 conditions. The values for all of these coefficients vary according to temperature and moisture conditions from year to year as well as from site to site; much of our research was aimed at analyzing the cause and extent of some of this variation.

Formulas for root growth, crown growth, and seed growth can be found in the unpublished reports of the US/IBP Desert Biome (Pearson 1975) but are not included here as they are more complicated, less precise, and of less direct interest to range

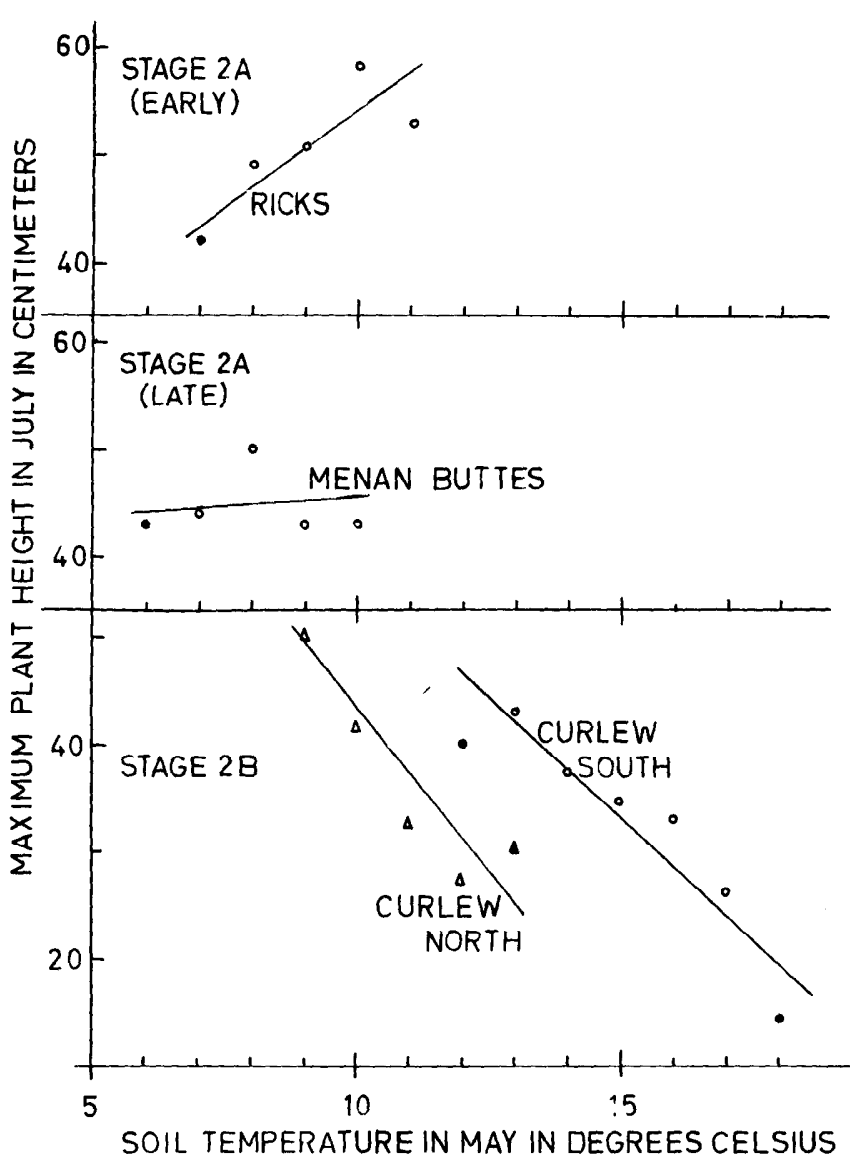

Fig. 3. Effect of soil temperature at 20-cm depth in early May on total plant height reached later in the season. In early May the Ricks College plants were in the early logarithmic phase of growth, the Menan Buttes plants were in late logarithmic phase, and the Curlew Valley plants were in the decelerating phase of growth. Closed symbols indicate average height of 1 to 3 plants, open symbols indicate average height of 4 to 10 plants.

managers.

In 1971, soil temperature adjacent to each plant was measured every 10 days; in 1973 some additional measurements were made. Within sites, temperatures varied as much as $6^{\circ}$ Celsius from one plant to another at any given moment; additional variation occurred from site to site. The locations that were the warmest in May were not necessarily the warmest in June. At the Sand Dunes site, higher soil temperatures during stage $2 b$ (late vegetative growth stage) delayed anthesis, 3 days for every increase of $1^{\circ} \mathrm{C}$ above $10^{\circ} \mathrm{C}$. Earlier, during stage $2 \mathrm{a}$, no correlation was noted between soil temperature and date of anthesis; however, Blaisdell (1958) reported that earlier anthesis was associated with higher stage 1 temperatures.

Maximum plant height was also correlated with soil temperature (Fig. 3). During early stage 2 the correlation was positive and relatively high. Each increase of one degree in soil temperature at this time produced $3.2 \mathrm{~cm}$ additional height at the Ricks College site. Gradually, the correlation became negative. By the middle of stage 2 , there was no correlation between soil temperature and final plant height $(b=-.1$ at Menan Buttes). Each increase of one degree during late stage 2 resulted in a decrease in final plant height of $4 \mathrm{~cm}$ at Curlew South and $6 \mathrm{~cm}$ at Curlew North. Correlation between maximum plant height and soil temperature was statistically significant at the Curlew IBP sites and at Ricks College.

During 1971, 2,964 measurements of crown diameter were 
Table 2. Harvest weight (g) of 104 Indian ricegrass plants following irrigation in May and June 1971 . Weight of crowns was highly variable and has been excluded. Weights followed by different letters are significantly different by the SNK test $(P<.05)$. Foliage weight differences, July 1 , were highly significant $(F$ test: $P<.01)$.

\begin{tabular}{|c|c|c|c|c|}
\hline & & Harves & (grams) & \\
\hline & Foliage & Roots & Seeds & Total \\
\hline $\begin{array}{l}\text { July } 1,1971 \text {, Harvest } \\
5 \text { plants given no water } \\
10 \text { plants watered only on May } 31 \\
10 \text { plants watered only on June } 25 \\
10 \text { plants watered both in May and June } \\
\text { plants given no water } \\
15 \text { plants given } 4 \mathrm{~cm} \text { water } \\
15 \text { plants given } 8 \mathrm{~cm} \text { water } \\
\text { Least significant difference }\end{array}$ & $\begin{array}{l}2.22 \mathrm{a} \\
3.39 \mathrm{~b} \\
4.46 \mathrm{c} \\
4.82 \mathrm{c} \\
2.22 \mathrm{a} \\
3.92 \mathrm{~b} \\
4.53 \mathrm{c} \\
.56\end{array}$ & $\begin{array}{l}4.00 \\
2.99 \\
2.50 \\
4.41 \\
4.00 \\
3.57 \\
3.03 \\
2.89\end{array}$ & $\begin{array}{l}.258 \\
.448 \\
.447 \\
.621 \\
.258 \\
.510 \\
.501 \\
.448\end{array}$ & $\begin{array}{l}6.48 \\
6.83 \\
7.41 \\
9.85 \\
6.48 \\
8.00 \\
8.06 \\
-\end{array}$ \\
\hline $\begin{array}{l}\text { July } 12,1971, \text { Harvest } \\
4 \text { plants given no water } \\
10 \text { plants watered only on May } 31 \\
10 \text { plants watered only on June } 30 \\
10 \text { plants watered both in May and June } \\
4 \text { plants given no water } \\
15 \text { plants given } 4 \mathrm{~cm} \text { water } \\
15 \text { plants given } 8 \mathrm{~cm} \text { water } \\
\text { Least significant difference }\end{array}$ & $\begin{array}{l}2.75 \\
5.29 \\
4.97 \\
5.29 \\
2.75 \\
5.33 \\
4.70 \\
1.98\end{array}$ & $\begin{array}{l}4.96 \\
3.61 \\
3.87 \\
1.80 \\
4.96 \\
3.56 \\
2.61 \\
1.83\end{array}$ & $\begin{array}{r}.438 \\
.819 \\
1.029 \\
1.010 \\
.438 \\
.979 \\
.927 \\
1.52\end{array}$ & $\begin{array}{l}8.15 \\
9.72 \\
9.87 \\
8.12 \\
8.15 \\
9.87 \\
8.24 \\
-\end{array}$ \\
\hline $\begin{array}{l}\text { August } 4,1971, \text { Harvest } \\
5 \text { plants given no water } \\
10 \text { plants watered only on May } 31 \\
10 \text { plants watered only on June } 30 \\
10 \text { plants watered both in May and June } \\
5 \text { plants given no water } \\
15 \text { plants given } 4 \mathrm{~cm} \text { water } \\
15 \text { plants given } 8 \mathrm{~cm} \text { water } \\
\text { Least significant difference }\end{array}$ & $\begin{array}{l}3.02 \\
5.49 \\
4.93 \\
4.77 \\
3.02 \\
5.79 \\
4.54 \\
2.51\end{array}$ & $\begin{array}{l}3.28 \mathrm{~b} \\
3.18 \mathrm{~b} \\
3.52 \mathrm{~b} \\
1.92 \mathrm{a} \\
3.28 \\
2.54 \\
3.20 \\
.81\end{array}$ & $\begin{array}{l}.058 \\
.122 \\
.355 \\
.313 \\
.058 \\
.247 \\
.279 \\
.182\end{array}$ & $\begin{array}{l}6.36 \\
8.79 \\
8.81 \\
7.00 \\
6.36 \\
8.58 \\
8.02 \\
-\end{array}$ \\
\hline
\end{tabular}

made, 988 in each of three directions: $0^{\circ}, 120^{\circ}$, and $240^{\circ}$ from north-south. Differences among the three directions were very highly significant $\left(\mathrm{F}=27.0, \mathrm{P}=2.78 \times 10^{-12}\right)$. The crowns tended to elongate in the north-south direction so that at $0^{\circ}(\mathrm{N}-\mathrm{S})$ the average crown was $7.924 \mathrm{~cm}$, at $240^{\circ}$ (ENE-WSW) 7.430 $\mathrm{cm}$, and at $120^{\circ}$ (WNW-ESE) $7.340 \mathrm{~cm}$. Apparently the additional warmth at the south and southwest sides of each clump in the early spring caused more rapid growth at $0^{\circ}$ and $240^{\circ}$ resulting in a measureable asymmetry over a period of years. The probability that differences were due to chance alone is so low that for practical purposes it can be considered an impossibility.

Average annual precipitation at the Plano site is about $19 \mathrm{~cm}$, varying from 13 to $26 \mathrm{~cm}$ over the years. The other Rexburg sites are about $15 \%$ to $45 \%$ wetter than Plano (Table 1). In 1971, there were no discernable differences in precipitation among sites or among individual plants within sites prior to June 15 . After June 15, both kinds of differences were pronounced (Table 1). Precipitation in May was $10 \mathrm{~mm}$ at almost every one of the gauges. June precipitation varied considerably: from 9 to $37 \mathrm{~mm}$ at the Ricks College site and from 10 to $67 \mathrm{~mm}$ at the Fremont County sand dunes. July precipitation varied at least as much. Some of the plant-to-plant variation was probably due to differences in evaporation of water from the gauges that occurred despite the film of oil in each gauge. The precipitation differences apparently came too late to affect the phenology of Indian ricegrass as no significant correlation between precipitation and growth or development of individual plants was detected at any of the four sites. Differences in growth and development among sites were significant, however, being greater at the wetter sites and least at Plano.

The irrigation treatments, on the other hand, increased foliage production and the increases were highly significant $(P<.01)$ for the July 1 harvest and closely approached significance on the other harvest dates (Table 2). The late irrigation was the more effective.

Estimates of increase in dry weight made from linear measurements were also significantly higher $(<.05)$ for plants irrigated in June (Table 3). Each centimeter of water applied increased foliage production $.32 \mathrm{~g}$ per plant according to the harvest data, or $.09 \mathrm{~g}$ per plant according to the estimated increase data; the discrepancy between the two values suggests a deficiency in the formula used to estimate dry weight in 1971. The early irrigation did not increase foliage production unless a relatively large amount of water $(8 \mathrm{~cm})$ was applied; even a small amount of water $(2 \mathrm{~cm})$ applied late increased foliage production, however (Table 3 ).

Seed weight also appeared to be increased by irrigation, the differences approaching significance at all three dates (Table 2). Root biomass, on the other hand, seemed to be decreased by irrigation, suggesting that additional water stimulated translocation of food reserves from the roots to the tops more than it improved rate of photosynthesis. The decrease was statistically significant for the August 4 harvest. At the Ricks College site, which was the only site at which grazing was excluded, the increase in the number of shoots per plant of the following spring was greatest on the irrigated plants. At all of the sites, the irrigated plants showed more evidence of grazing by livestock, rodents, or insects than the non-irrigated plants; this was most pronounced at Plano, where differences were statistically significant. On a scale of $0=$ no evidence of grasing to $50=$ evidence of very heavy grazing, plants receiving no irrigation scored 14, those irrigated only on June 25 scored 21.5, those irrigated only on May 31 scored 28.5, and those irrigated both 
Table 3. Effects of irrigation on increase in estimated biomass and on date of anthesis. Biomass measurements were made on 140 Indian ricegrass plants at the Rexburg sites in the middle of May and middle of July; date of anthesis data are from 35 plants at the Fremont County Sand Dunes site.

\begin{tabular}{|c|c|c|c|c|c|}
\hline & \multicolumn{3}{|c|}{ Increase in est. dry wt. } & \multicolumn{2}{|c|}{ Time to beginning anthesis } \\
\hline & No. plants & Foliage $(\mathrm{g})$ & Seed $(g)$ & No. plants & No. days \\
\hline $\begin{array}{l}\text { Plants given no water } \\
\text { Plants watered only on May } 31 \\
\text { Plants given no water until June } 30 \\
\text { Plants watered in both May and June } \\
\text { Plants given no water } \\
\text { Plants given } 4 \mathrm{~cm} \text { water } \\
\text { Plants given } 8 \mathrm{~cm} \text { water }\end{array}$ & $\begin{array}{l}20 \\
40 \\
40 \\
40 \\
20 \\
60 \\
60\end{array}$ & $\begin{array}{l}.33 \mathrm{a} \\
.45 \mathrm{~b} \\
.65 \mathrm{c} \\
.67 \mathrm{c} \\
.33 \mathrm{a} \\
.54 \mathrm{~b} \\
.64 \mathrm{~b}\end{array}$ & $\begin{array}{l}.58 \\
.50 \\
.78 \\
.74 \\
.68 \\
.77 \\
.56\end{array}$ & $\begin{array}{l}5 \\
10 \\
10 \\
10 \\
5 \\
15 \\
15\end{array}$ & $\begin{array}{l}70 \mathrm{a} \\
81.5 \mathrm{~b} \\
73.5 \mathrm{a} \\
80 \mathrm{~b} \\
70 \mathrm{a} \\
75 \mathrm{a} \\
82 \mathrm{~b}\end{array}$ \\
\hline Least significant difference & & .15 & NS & & 5 \\
\hline $\begin{array}{l}\text { Specific treatments } \\
0-0 \\
4-0 \\
8-0 \\
0-4 \\
0-8 \\
2-2 \\
4-4\end{array}$ & $\begin{array}{l}20 \\
20 \\
20 \\
20 \\
20 \\
20 \\
20\end{array}$ & $\begin{array}{l}.33 a \\
.31 \mathrm{a} \\
.59 \mathrm{~b} \\
.61 \mathrm{~b} \\
.69 \mathrm{~b} \\
.69 \mathrm{~b} \\
.64 \mathrm{~b}\end{array}$ & $\begin{array}{l}.68 \\
.58 \\
.42 \\
.81 \\
.74 \\
.93 \\
.54\end{array}$ & $\begin{array}{l}5 \\
5 \\
5 \\
5 \\
5 \\
5 \\
5\end{array}$ & $\begin{array}{l}70 a \\
80 b c \\
83 b c \\
70 a \\
77 b \\
75 a b \\
85 c\end{array}$ \\
\hline
\end{tabular}

times scored 29.

Percent of ground between clumps of grass covered by annual weeds increased during the spring of 1971 until June 24, when it reached $10.9 \%$. As the weeds matured and dried, their cover declined to $1.7 \%$ on July 14 and $0.35 \%$ on August 3 . On August 3 , percent weed cover was significantly higher near plants that had been irrigated, the difference being due primarily to the early irrigation and directly proportional to the amount of water applied.

Over 150 Indian ricegrass plants were harvested in 1971 and an additional 22 in 1972; comparisons between the weights of the harvested plants and their linear dimensions led to the development of several formulas (Pearson 1975). Foliage dry weight and the fruit-seed dry weight were quite accurately estimated from the following formulas:

$$
\begin{aligned}
& Y_{f}=K_{1} A C L+K_{2} D+K_{3}(S N)^{1 / 2}+K_{4} \\
& Y_{f}=8.15 \times 10^{-5} \text { ACL }+.18 D+.054(S N)^{1 / 2}-.61 \\
& Y_{S}=.00495 S N+.0029 A-.0026 H-.0158
\end{aligned}
$$

where $Y_{f}=$ foliage dry weight in grams and $Y_{s}=$ seed head dry weight in grams, $\mathrm{A}=$ average leaf length in $\mathrm{cm}, \mathrm{C}=$ number of culms per plant, $\mathrm{L}=$ average longest leaf in $\mathrm{cm}, \mathrm{D}=$ average crown diameter in $\mathrm{cm}, \mathrm{S}=$ number of seeds per head, $\mathrm{N}=$ number of seed heads per plant, and $\mathrm{H}=$ average height of the seed stalks in $\mathrm{cm}$. Formula (6) is a generalized formula for use with any cool season bunchgrass once the coefficients $K_{1}, K_{2}$, $\mathrm{K}_{3}$, and $\mathrm{K}_{4}$ have been ascertained by harvesting a number of plants. Formulas (7) and (8) apply to Indian ricegrass growing at the Rexburg sites in 1971 and 1972. Good estimates of foliage and seed head dry weights were obtained with these two formulas at all six sites; nevertheless, Indian ricegrass growing at other locations or time might require some slight adjustments of the four coefficients in each formula.

Obtaining accurate estimates of foliage or seed dry weight depends on making accurate and reproduceable measurements of the necessary linear dimensions. The following aided us in making our measurements: (1) Four long galvanized spikes were driven into the ground around each plant at the time of the first measurement so that the heads of the spikes were flush with the top of the crown where the new green foliage originates, and all subsequent measurements of leaf length and plant height were made from the tops of these spikes. (2) A light-weight, steel measuring device (calipers) for obtaining crown diameter was prepared; it has two parallel sides which can be adjusted to any width from 0 to $50 \mathrm{~cm}$ by sliding one arm along an iron rod welded at right angles to the other arm. (3) Three brightly colored rods, each about $30 \mathrm{~cm}$ long, were used to divide the plant into seven sections so that keeping track of the number of culms counted was better facilitated. Our earliest estimates were made without the aid of these devices and were less accurate

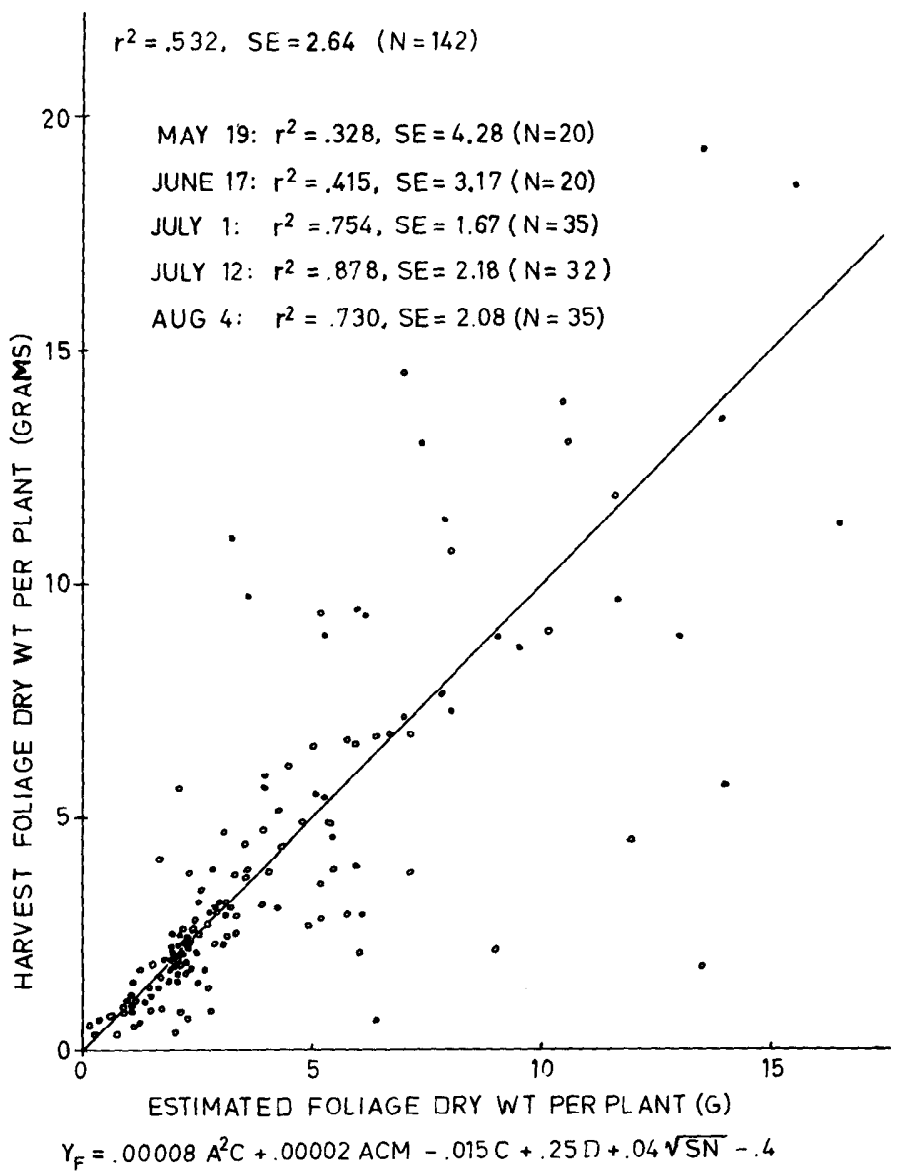

Fig. 4. Scatter diagram plotting actual dry weight against estimated dry weight of foliage. Better correlations were obtained later in the season as measuring of the parameters used to estimate dry weight became more consistent. $M$ is maximum leaf length: see text following formulas (6) to (8) for other symbols. 


\section{than the later estimates.}

Figure 4 is a scatter diagram of harvest dry weight plotted against estimated dry weight. The formula used was slightly different from formula (7) as we did not keep average longest leaf (L) data in 1971. Correlation was better later in the season. As the parameters needed were more consistently measured, $r^{2}$ increased from .328 in May to .878 in July. In August, tips of leaves were brittle and often broke as the plants were handled, making accurate estimation of leaf length more difficult. When average longest leaf data became available in 1972 there was further improvement in estimating dry weight.

Needleandthread grass went through the same phenological stages as Indian ricegrass but reached maximum size somewhat earlier. Irrigation increased the amount of foliage produced and delayed the time of reaching maximum leaf length. The $2 \mathrm{~cm}$ application of water in late May had no effect on production, but each additional centimeter of water increased foliage dry weight in July by about $.15 \mathrm{~g}$ per plant. Each centimeter of water applied May 31 delayed leaf length attainment about 2 days. This prolonging of stage 2 a (logarithmic growth stage) should account for at least part of the increase in weight associated with early irrigation of the plants. The early irrigation also retarded fowering of some of the plants at the Ricks College site, one of them by about 30 days. The June 25 irrigation seemed to stimulate a second spurt of growth immediately following irrigation, especially at the Menan Buttes site.

\section{Discussion and Conclusions}

A change in weather during one phenological stage may produce a markedly different response in Indian ricegrass from an identical weather change during a different phenological stage. This needs to be kept in mind when managing rangeland. Pearson (1964) suggested that many of our ranges could support larger populations of livestock with less damage to the range if more attention were paid to the season of grazing. A critical period during which cool season bunchgrasses are very susceptible to overgrazing seems to be phenological stages $2 \mathrm{~b}, 3 \mathrm{a}$, and $3 \mathrm{~b}$, (from the beginning of the decelerating phase of the vegetative growth stage through the anthesis and maturation stage). During this time, grazing should be greatly reduced or even totally eliminated if the desirable species are to be properly protected. If the spring is cool or moist, the beginning dates of these stages will be later, which should allow early spring grazing to continue longer; however, the ending dates will also be later, necessitating holding animals off the range longer into the summer.

Examination of Figure 2 helps explain why management of grazing is so critical during the late vegetative and anthesis stages: the roots during much of this time are losing weight, and this tendency is more pronounced when more moisture is available. The study of roots and their contribution to the total energy budget of a plant is a difficult task and therefore frequently ignored. It takes much more time to excavate and weigh roots than other plant parts and much more care must be exercised in handling roots as they easily break. Nevertheless, we cannot analyse accurately the patterns of growth and development in plants without adequate information on root mass.

The advantages of estimating dry weight from plant height, leaf length, and other linear measurements include: (1) ease of evaluating a large number of plants in a short period of time, (2) ability to make successive measurements on the same plant and hus observe its rate of growth more accurately, (3) less damage to the ecosystem, and (4) selection of similar plants for grouping into replications prior to beginning an experiment which may or may not involve harvesting later on. There was good correlation in this study between estimated dry weight and harvest dry weight for foliage and seed stalks. It was more difficult to estimate root weight and crown weight accurately. However, number of roots per plant was rather highly correlated with crown diameter while the weight of individual roots was positively correlated with average leaf length and negatively correlated with number of seed heads: consequently, even root biomass was estimated fairly accurately in 1971, suggesting that it may be possible to develop good formulas in which we can place confidence for future work. We ascertained that it took 14 to 20 man minutes per plant on the average, dependent on the experience of our data gatherers, to gather and record all of the linear measurements needed to estimate the weight of the plant, and $2 \frac{1}{2}$ to $3 \frac{1}{2}$ man hours per plant to harvest, weigh, and record the actual dry weight data of the same plant. Hence, any success in estimating even foliage dry weight accurately can be of great time saving value in studying the effects of moisture, temperature, or other factors of the environment on the phenology and productivity of rangeland species. We recommend the use of devices similar to those we employed in this study to improve the accuracy of estimating dry weight.

Indian ricegrass begins growth slightly later than most of its associates among the cool season bunchgrasses. According to Blaisdell (1958), the sprouting stage for Sandburg's bluegrass (Poa secunda Presl) begins while soil temperatures are about $0^{\circ} \mathrm{C}$, or as soon as the snow disappears; for Nevada bluegrass (Poa nevadensis Vasey ex Scribn.) and prairie junegrass (Koeleria cristata (L.) Pers.) it begins slightly later, and for bluebunch wheatgrass (Agropyron spicatum (Pursh.) Scribn. and Smith), thickspike wheatgrass ( $A$. dasystachyum (Hook.) Scribn.), and needleandthread grass it begins still later, or about the same time as Indian ricegrass. Also, according to Blaisdell, Indian ricegrass matures more rapidly than most other coolseason grasses. Sandburg's bluegrass and needleandthread grass matured even more rapidly than Indian ricegrass at the six sites included in this report.

From the configuration of the growth curve of Indian ricegrass, four phenological stages are apparent. If the soil warms up rapidly during the first of these, yields will be better than if the season is late or the soil remains cold. Increased soil moisture is usually accompanied by lower soil temperatures and therefore seems to be nonbeneficial during this stage of development. During the second or vegetative growth stage, moisture is of greater significance. Higher soil temperature at this stage is generally associated with low soil moisture and is therefore no longer beneficial. Judging from our observations on needleandthread grass, Indian ricegrass should provide a good model for other cool season bunchgrasses. As we learn more about the phenology and productivity of the important grasses, management of rangeland becomes more meaningful.

\section{Literature Cited}

Blaisdell, J.P. 1958. Seasonal development and yield of native plants on the upper Snake River plains and their relation to certain climatic factors. U.S. Dep. Agr. Tech. Bull. No. 1190. 68 p.

Chadwick, H.W., and P.D. Dalke. 1965. Plant succession on dune sands in Fremont County, Idaho. Ecology 46: 765-779.

Ezekiel, M. 1941. Methods of Correction Analysis. 2nd Ed. John C. Wiley; N.Y. 
McMillan, C. 1959. The role of ecotypic variation in the distribution of the central grassland of North America. Ecol. Monogr. 29: 285-308.

McMillan, C. 1961. Nature of the plant community. VI. Texas grassland communities under transplanted conditions. Amer. J. Bot. 48: 778-785. Pearson, L.C. 1964. Effect of harvest date on recovery of range grasses and shrubs. Agron. J. 56: 80-82.

Pearson, L.C. 1965. Primary production in grazed and ungrazed desert communities of eastern Idaho. Ecology 46: 278-285.
Pearson, L.C. 1975. Effects of temperature and moisture on productivity of Oryzopsis hymenoides. Unpublished Progress Report, US/IBP Desert Biome Research Memorandum 75-6 In: Reports of 1974 Progress 3: 19-34, Utah State Univ., Logan.

Robertson, J.H. 1977a. The autecology of Oryzopsis hymenoides. Mentzelia 2:18-21, 25-26.

Robertson, J.H. 1977b. Indian Ricegrass-Casanova of the western range. Rangeman's J. 4: 138-139. 